\title{
The Covid-19 Pandemic and Religious Activities: A Case Study of Esikhaleni Settlement
}

\author{
Lawrence Korsi, Vorvornator \\ University of Zululand, KwaDlangezwa, 3886, South Africa \\ Email: vorlaw@gmail.com \\ ORCID ID 0000-0002-4475-6665 \\ Joyce Mdiniso \\ University of Zululand, KwaDlangezwa, 3886, South Africa \\ University of Zululand South Africa \\ Email: MdinisoJ@unizulu.ac.za \\ ORCID ID: 0000-0001-9618-49 \\ Doi:https://doi.org/10.46222/pharosjot.102.213
}

\begin{abstract}
The COVID-19 virus allegedly originated from Wuhan, China and spread globally including South Africa and forced the country into restricted lockdown. This study analyses COVID-19 and religious activities during lockdown among dwellers in the rural community of Esikhaleni in South Africa's KwaZulu Natal province. A qualitative approach was employed including thirty participants who were selected through random sampling. Telephonic interviews were conducted with the respondents from $1^{\text {st }}$ to $30^{\text {th }}$ May, 2020. Durkhein's ideas of functional religion in Sociology relating to the human race being together, sharing solace and love with the destitute were defied by COVID-19 protocols. These protocols of the state implemented social and physical distancing to be observed to curb a high infection rate (WHO, 2020). As a result social gatherings were halted, which posed severe challenges to religious bodies to meet, praise and worship as the normally do. Some religious bodies then, resorted to online approaches and used media platforms such as, Zoom, Skype, and even WhatsApp to deliver their services. Major events by some religious organisations including baptisms, crusading, evangelism, and Hajj pilgrimages by Muslim adherents were also postponed. The COVID-19 catastrophe befalling the destitute and needy in society forced religious bodies to extend their arms to those in dire need of help. Challenges during the use of online services included both leaders and congregants not having the requisite technical know-how to connect the programmes. There were also issues related to network connectivity, intermittent power interruption, and the inordinately high cost of data procurement in South Africa for especially the poor. Overall, despite COVID-19 protocols preventing social gatherings, religious bodies, developed other means to keep their spiritual tempo and ought to overcome a sense of hopelessness bestowed on congregants by the pandemic - but sadly this omitted the poor. It is recommended that, religious leaders must learn to use ICT effectively, because COVID-19 might be here for some length of time to come. Moreover, religious leaders must also strive to educate their congregants to observe COVID-19 protocols and seek to avoid a third imminent wave of the virus, instead of laying blame at the door steps of government. Religious orders need to urgently embrace technological solutions which is sadly not always possible due to limited resources. Getting the masses out of poverty through job creation would also go a long way to help when future pandemics arise, and they surely will.
\end{abstract}

Keywords: Lockdown, religious bodies, pandemic, covid-19, Esikhaleni settlement.

\section{Introduction}


The pandemics, crises, emergencies, plagues and disasters such as bush fires, drought and floods are inevitable in man's life. More so, for such crises to be global in orientation or to be declared as a pandemic, is not far-fetched so far as religious activities such as pilgrimages, crusades and evangelism are concerned. Such pandemics also affect, globalisation, international trade, international tourism, and lead to a rapid and massive growth of the technology needed to keep 'afloat' (Mbogo, 2020). Because, religious activities, global tourism and trade activities are bonded, interwoven and entangling nations the world is described often as 'a global village' (Kang et al., 2020). Zamoun and Gorpe, maintain that:

\begin{abstract}
What constitutes the crises are not easily agreed......upon, however, despite lack of clarity, there are specific conditions of crises in the crises literature.... For example, crisis situations share six characteristics which are.... rare, significant, high impacts, ambiguous, urgent and involves high stakes......Crisis involves the period of discontinuity, a situation where the core values of organisations or systems are under threat, and thus requires the critical decision-making. There is a destabilising effect of the organisations, and its shareholders and escalation of one or more issues, errors and procedures are expected in this period...(Zamoun and Gorpe, 2018).
\end{abstract}

To Arjen et al (2007) the crisis approach is made up of three components including threats, uncertainty and urgency. Therefore, the COVID-19 pandemic poses a crisis to human race and organisations including religious bodies in all faiths.

Wuhan, in Hubei province in China which served as the epicentre for the COVID-19, could not contain the novel coronavirus, which then spread rapidly like a bush-fire across the globe. In less than no time the infection rate reached 800, 000 in March, 2020. Hereafter, the COVID19 was declared to be a global pandemic (World Health Organisation , 2020; Worldometers, 2020; New York Times, 2020). The novel coronavirus affected all sectors of human endeavour, economic and also social, and caused emotional and psychological trauma as it affected religious activities across the globe.

The yearly Abrahamic religious traditions observed by Christians, Islam and Judaism between February to April 2020 were massively affected by the advent of the COVID-19 pandemic and the Jewish Passover was also affected., Christians, of the Nazareth Baptism Church (Shembe Church), Zion Christian Church (ZCC), Esther were also affected. Muslims, were unable to effectively experience Ramadan as well as partake in the annual Hajj pilgrimage to Mecca, Saudi Arabia. Religious gatherings often involve travellers who could bring communicable diseases to the host nations. The crowding that results usually leads to a spread of diseases and infection. For instance, the Hajj pilgrimage normally pulls people from all walks of life close to about 2 to 3 million (Shafi et al, 2008). The Christian Lourdes pilgrimage of Catholics in France, celebrated every year gathers over 5 million pilgrims from across the globe (Gautret \& Steffen, 2016). There are many destinations and sites that are by their very nature of great religious, cultural, architectural or historical value and consequently of great interest to both domestic and foreign tourists. If there are deficits in marketing communication, poor infrastructure and other areas, this could hinder the development of pilgrimage and religious tourism which is a huge sector and niche market and in times of pandemic this could be catastrophic (Nicolaides, 2016; Frey, 2004).

The Kumbh Mela is not forgotten in India. It is celebrated once every three years alternatively along the banks of four holy rivers. It is arguably the largest religious gathering in the world which could gather well over 120 million pilgrims worldwide (Memish et al, 2019).

A festival such as the Kumbh Mela with its millions of pilgrims can easily turn into a superspreader event as huge groups of pilgrims without face masks sit on the river bank and thuscreate an perfect environment for a virus such as COVID-19 to rapidly spread. Consequently, many mass movements such as sports, traveling and social, cultural 
gatherings were also halted, notably among them was the Olympic games which were supposed to be hosted in Tokyo (BBC, 2020).

In addition, small gatherings for worshipping and prayers may also create a significant risk of infection. This brings to mind Indiana in the USA and there Church services where a 17 years old girl from Romania was unvaccinated and she infected others resulted in an outbreak of measles (Parker et al, 2006). Moreover, in Rwanda among Christian gatherings of only 200 congregants in 2012, there was an outbreak of salmonellosis (Nzabahimana et al, 2014). Recently, the news across the globe about the Church crusade in Shincheonji Church of Jesus in Daegu, South Korea on the 18 February, 2020 caused an increase in the infection rate of COVID-19 pandemic to 30 patients (McLaughlin, 2020). Such happenings have at times forced various governments across the globe to clamp down on religious activities as well as obliged them to institute restricted lockdown orders in order to curb the rate of pandemic infection.

In South Africa, the lockdown aimed to ensure that health personnel are psychologically prepared and resources gathered so that the health system could not be over-stretched (The Presidency, 2020). Also, the cycle of transmission could in part be halted as well by observing the 3 C's; avoiding closed spaces, crowded places and close contacts. The South African infection rate was very low compared to Italy and America the South African government took decisive decision to implement stringent lockdown rules from 26 March, 2020 to 30 April 2020 to avoid a risk of straining the limited health system.

The study seeks to answer a number of pertinent questions relating to the pandemic and its effect on the rural settlement of Esikhaleni. How did the religious bodies respond to the lockdown for their sacerdotal services to the congregants? What are the approaches adopted by the religious institutions to meet their daily and spiritual needs for the followers? What roles play by the religious organisations to assist destitute and vulnerable in society? What challenges were there in implementing new approaches for the 'new normal' life under religious activities?

This study adopted a phenomenological approach and used a qualitative method to collect data from the respondents form Esikhaleni in order to explore the processes used by the religious bodies for their devotees and congregants to ensure their daily spiritual needs were met. The study also explored some challenges that arose in implementing new measures under COVID-19 protocols and lastly the researcher made recommendations to mitigate challenges for future occurrences of this nature. The Esikhaleni Township was selected because it is multi-faith and multi-cultural nature (Statistics South Africa -Stats SA, 2015).

\section{Study Area}

Esikhaleni as it is currently called was known as Esikhawini, which is a Zulu word meaning "the meeting point of the sea". Esikhaleni was established in the year 1976 (Zulu Kingdom, 2008). It is located in the King Cetshwayo District of the KwaZulu-Natal, South Africa. The people are from diverse backgrounds with Zulus comprising 70.8 percent of the population which is also multi-faith and multi-cultural (Stats SA, 2010). The socio-economic status of the township (ekasie) dwellers is described to be low income. As of 2001 the population was 32,437 and in 2010 the township dwellers increased to 49,265 (Stats SA, 2010). The density of Esikhaleni is $5,500 \mathrm{~km}^{2}$ and is located $2 \mathrm{~km}$ of the $\mathrm{N} 2$ route and the closest towns are Empangeni and Richards Bay with 15-20 km apart (Stats SA, 2017). Esikhaleni is the home of Ecubhu Lake and the King Cetshwayo monument where it is on the record that, King Cetshwayo boarded a ship to be imprisoned in Cape Town after the defeat of the Zulu nation by the British in the 1879 Anglo Zulu war (Impact, Economic Strategies of Zululand, 2007). 


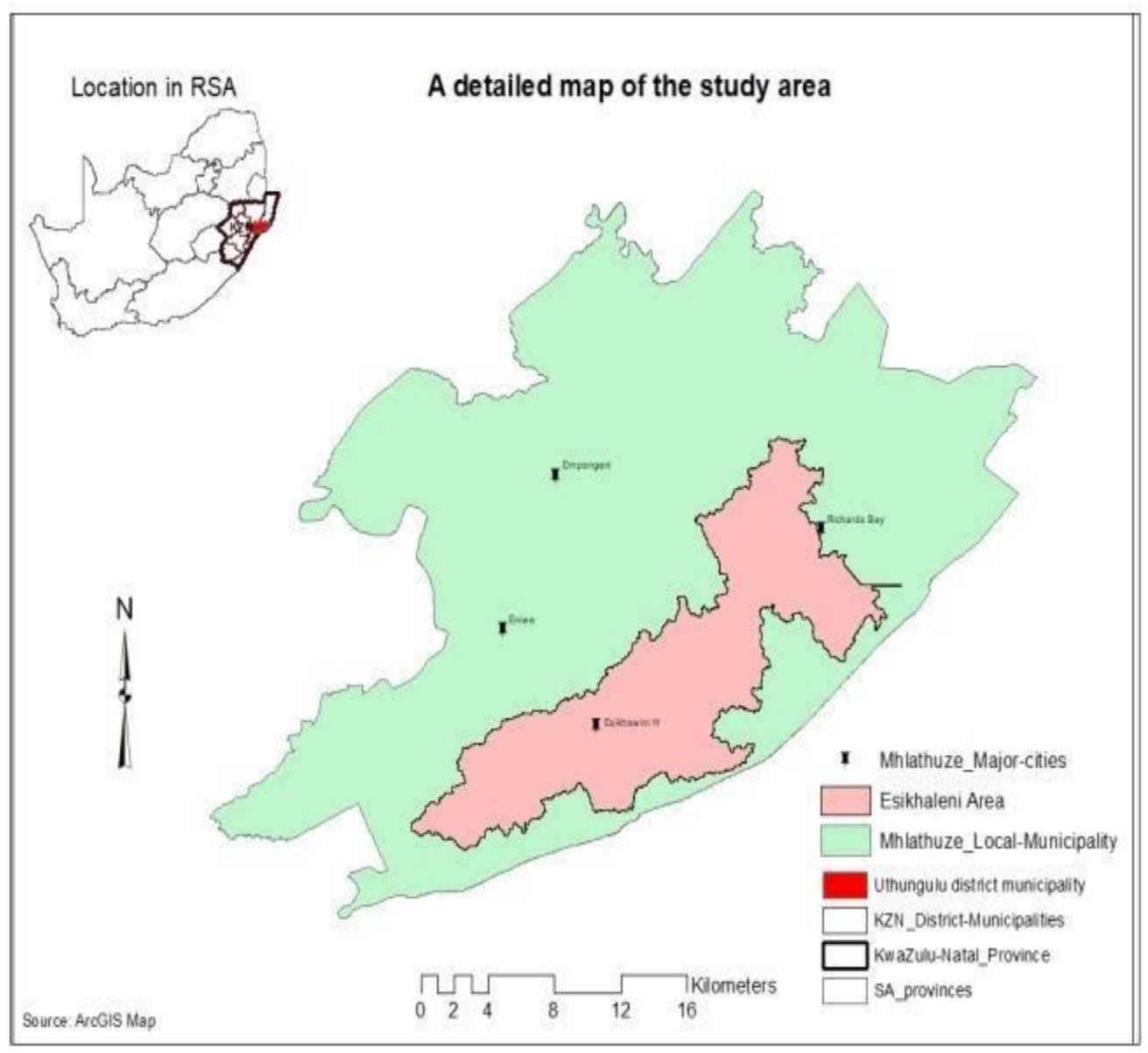

Image 1. Study area of Esikhaleni in South Africa (in pink)

\section{Literature Review}

The COVID-19 pandemic protocols such as social distancing and physical distancing defy as well as disobey the Durkhein theory of religious functioning from a sociology perspective. Durkhein's ideas of functional religion maintains that there should be social integration, love, solace, caring and sharing among the individuals, and also security through a collective culture to provide solutions for the destitute and vulnerable in societies (Durkhein, 2005). However, the advent of COVID-19 poses a threat of huge proportion for the solace, security and safety of individuals as well as loved one's under threat of illness and possible death, hence, a restrictive lockdown was implemented (The Presidency, 2020).

The stringent lockdown wiped away and created ripple effects affecting religious-based activities, and socio-cultural rituals and events which had to be cancelled. In Japan, events such as sumö tournament i, Gion matsuri in Kyoto, Awa Odori dance festival in Tokushima and Tanabata anniversary in July and Obon which are celebrated to commemorate the ancestors were all cancelled as a result of massive spread of the COVID-19 pandemic. The COVD-19 pandemic wreaked havoc, devastated people and in a sense tormented shrines, temples and churches as well as religious communities and organisations making the entire population who became highly disorientated (Douglas, 1994). Moreover, with shrines, temples and churches cancelling events and downsizing their ceremonies as well as rituals as a result of COVID-19 pandemic, this made individuals' wonder where the remedy would come from to cope with the growing COVID-19 infection rate (Douglas, 1994). Easter, Passover, and Ramadan, which happen within weeks of each other in April, were faced with major interruptions due to social distancing policies. For example, pilgrims eager to visit the Christian, Jewish, and Islamic holy sites in Jerusalem had to experience the two weeks of quarantine 


\title{
Re-Branding ways of worship and devotion amidst the COVID-19 pandemic
}

In Japan, it was documented that the traditional religious institutions embraced Digital Communication Technology (ICT) at paramount functions. Therefore, religious communities, temples, shrines and churches moved away from orthodox as well as traditional way of faceto-face meetings for their rituals, worshipping and prayers (Cavaliere, 2020). It could be that the switch to online services was to provide as well as revive the hopelessness, stress and anxiety that COVID-19 pandemic bestowed on the population (Cavaliere, 2020).

The Daibutsu (Great Buddha Hall) in Japan which served as a home to a 15 million population was completed in the year $752 \mathrm{CE}$, in the aftermath of severe crop failures and a devastating smallpox epidemic. It was believed that, it would protect the Japanese from infectious diseases, and during the period of restricted lockdown, windows were opened for passers-by to see it from afar and pay respect and worship. Since the COVID-19 pandemic, it was also believed to be an infectious disease spreader (Cavaliere, 2020). Meanwhile, the windows of the Great Buddha Hall were only open for ten days during August in the Obon festival and around the New Year's eve On the Tõdaiji website it was written that:

\begin{abstract}
Prayers are always with Great Buddha during difficult times. The temple is supposed to be a place for people, to visit and pray at any time. Therefore, we will not completely close our gates. We believe it is time for us to put our efforts into global cooperation's and efforts towards ending the pandemic (https://www:tõdaiji.orjp).
\end{abstract}

Regarding stay-home protocols Buddhist Schools in Japan resorted to digital transmission namely O-uchi de otera (Buddhism at home). 'Reading of the Sutra online' involved reciting sutras and prayers at an appropriate time on Twitter and Facebook which were adopted to educate the monks about how to pray in their homes (https://www.facebook.com/reading sutras. Online). The shrines modernisation to the use of the digital technology to render services was not left out in Japan. The shrines also provided three main votive tablets that the followers memorise each day through online proceedings:

\begin{abstract}
Safe commuting and work: I pray to be protected for being infected by COVID19 while commuting to work or at workplaces. Praying for swift end of the COVID-19 pandemic: I pray for an immediate return to normal life with a smile as soon as possible. Family safety: I pray for my partner, my family and myself to stay healthy, without being affected by COVID-19 and for a swift end of the pandemic (https://www.facebook.com/reading sutras. Online)
\end{abstract}

Various expressions by the participants about online votive tablets expressed their pleasure on Facebook and Twitter indicating the success of the programme as such.

Shrines also engaged with adherents in their services through the post and not only online, since the followers were not allowed to travel to collect amulet charms and concoctions during a restricted lockdown. For instance, Katori Jinga in Saitama Prefecture, a very well-known and famous shrine among the mothers and will-be-mothers delivered amulets charms and concoctions to their clients through the post upon request by the clients through emails and telephonic conversations (Cavaliere, 2020). Moreover, to comply with the lockdown regulations in terms of avoiding closed spaces, closed contacts and closed doors, some shrines moved their objects of devotion to the outside of buildings for the passers-by to pay homage and say their prayers without going into the rooms in the buildings. A typical example in mind is the Ishiyamadera in the city of Otsu, Shiya Prefecture displaying a five metre high statue of a ao oni (blue diamond), at the public and recreational parks to avoid people going inside the room for worships and prayers as well as devotions (Cavaliere, 2020). The blue diamond is usually displayed in May each year for passers-by to pay their homage, because it isbelieved that the founder became a demon after death and he vows to protect its temple and the community (http://www.yputube.com). On the same note Amabie the blue diamond of Ishiyamadera is known to cast away evil spirits and bring good health and prosperity to 
people, and this too was also displayed in recreational parks for people to worship (http:www.ishiyamadera.or.jp).

Not only online and postal services were implemented during lockdown for devotional services. Videos and Zoom were also employed in Japan and across the globe. The most prominent among them was the video which went viral on 20 May, 2020 about images of the past, a $o$ oni festival activities with massive amounts of worshippers joining in prayers and devotion. The video clips concluded by showing the display of the blue diamond in the public park with its fresh green leaves indicating that the blue diamond was moved outside for the passers-by to worship during the restricted lockdown period.

In regards to the aforementioned above, the movement of the devotional objects to the public parks and recreational areas for the passers-by to worship and pay their homage explains how culture is indeed dynamic and not at allstatic. It further explains that praying and worshipping is beyond physical distancing and isolation measures.

\section{Embracing ICT amidst of COVID-19 Pandemic}

The outbreak of COVID-19 which occurred on the 18 February, 2020 in South Korea after worshipping in the Shincheonji Church of Jesus in Daegu, where 30 congregants were infected by the COVID- 19 pandemic sent shock waves to the world leaders as well as the religious leaders across the globe (WHO, 2020). Religious gatherings proved themselves to be hotbeds for outbreaks and it is estimated that half of South Korea's cases can be traced back to a meeting of the Shincheonji Church of Jesus (Robinson, 2020).

Some of them decided to use online methods for meeting with their congregations, and also for worshipping and prayers. The online approaches instead of the orthodox face-to-face worship grewas the movement of the people was halted by the various lockdown rules and regulations. As a result, most religious leaders heeded to the call by cancelling collective worshiping and rituals and started to use online techniques such as Microsoft Teams, Facebook, Zoom, Skype, Videos as well as YouTube (McLaughlin, 2020).

More so, study groups were also conducted online. The screening of the religious activities became the order of the day. For instance, on the 14 April, 2020 the Hindu ancestral prayers were live screened (Alagesh, 2020). Christian Easterer services were no exception. The online weekly worship and live Easter services were performed for the 'whole world' to see and experience (Naidoo, 2020: The Star, 2020b). Not only Christian and Hindu services were aired. The Qing Ming (Chinese Memorial Day) which was being observed by the Chinese before the COVID-19 pandemic outbreak was screened to the people to be commemorated and celebrated in their homes instead of visiting the tombs as was the custom (Ebrahim \& Memish, 2020). More so, wedding activities as well as circumcision ceremonies were cancelled and instead replaced with simpler ceremonies, which in some instances allowed for connection on the Microsoft Teams and Zoom platforms. (

The trend was not that much different among the Nigerian religious leaders and their stances, however, it must be noted that most of the Nigerian Christian houses used mostly television broadcasting as well as secured various channels for their services from March, 2004 as a result of the clamp down on the religious activities in the country at the time $t$ (WotogbeWeneka, 2012). With the advent of COVID-19 and its lockdown the online services were intensified as well as extended onto Facebook, YouTube, Twitter, WhatsApp, and Messenger among others to accommodate the mass congregants from their home (Wobodo, 2020). Through online mediums, sermons, worship, evangelism and prayer sessions were made available to the congregants to keep their spiritual tempo up irrespective of hopelessness perpetrated by COVID-19 pandemic. The Christian Association of Churches in Nigeria which serves as the mother body of the country's Christian denominations also endorsed the use of online mediums of communication to curb the spread of the COVID-19 infection (Wobodo, 2020). 
In order to keep religious bodies operating and delivering on their online goals, some pastors notably the United Kingdom (UK) based Nigerian pastor who is also the head pastor of Kingsway International Christian Centre (KICC) requested their members to send their tithes, pledges, seeds of offering and offerings online to the Church's bank account. The members were also encouraged to make deposits into the banks account electronically by the use of electronic fund transfer payment (EFT) (pmnewsnigeria.com, 2021).

The shift toward mediated communication for interactive rituals, groups and organizations that already emphasized the use of such technologies before the imposition of social distancing requirements have a clear competitive advantage for the maintenance of their organizations compared to groups who were more heavily reliant on face-to-face interactions. Streaming services, both live and recorded, have become more common recently, and many congregations had already invested in the equipment and personnel to provide access to their services remotely. Regarding communal rituals such as weddings, technology has been used to allow small in-person gatherings while providing remote participation for broader networks of family and friends. Similarly, in relation to bereavement and death, online options have opened to conduct funeral services that allow involvement and interaction through video. Organizations' access to capital resources will affect their ability to upgrade communication technologies to substitute for face-to-face gatherings during periods of social distancing. (Baker et al, 2020)The use of ICT is not to uplift the spirit of the congregants alone, but also, gave voice to the religious leaders across the globe to express their ideas, views and opinions about the novel COVID-19 pandemic worldwide which is unprecedented in the history of human race. On the 18 April, 2020 the senior pastor of Christ Embassy Church (CEC) Dr, Chris Oyakhilome sermon or homily to the congregants through online services across the globe claimed that COVID-19 is never a natural disaster, but rather, connected to $5 \mathrm{G}$ technology aimed at reducing the African population (Awoshiri, 2020). In the words of pastor Oyakhilome:

There is no need for a vaccine, these are the part of Antichrist's plan for the new world order where some figures of authority of the world were trying to build a religious economy and government of the entire universe (Awoshiri, 2020).

The homily was considered to be harmful about the causes and treatment of the global pandemic COVID-19. In that regard, Loveworld channel which belongs to CEC was sanctioned in UK by Ofcom broadcasting authorities (www.vanguardngr.com). In rebuttal, senior pastor of KICC, Ashimolowo strongly disagreed with a sermon of Pastor Oyakhilome through online platforms that COVID-19 has nothing to do with $5 \mathrm{G}$ and Antichrist as alluded by head pastor of CEC. When people need to worship in a different circumstance it becomes a challenge for many (McGuire, 2008).

In another development, Apostle Sulemana of Omega Fire Ministries International also postulates in one of his online services to the congregants that COVID-19 is a chemical born disease (Awoshiri, 2020). Meanwhile, E.A Adebayo senior pastor of Redeemed Christian Church of God (RCCG) insisted that COVID-19 is a 'divine holiday' from the Creator. He further alluded that the COVID-19 pandemic is a way the Almighty God is expressing His supremacy over the human race (Awoshiri, 2020). Adebayo elaborated that the arithmetical infection rate of the pandemic across the globe irrespective of being a developed or developing country, explains that political, economic and social powers cannot stop the COVID-19 pandemic apart from the intervention of God alone (Awoshiri, 2020).

\section{Benevolent Roles of Religious Bodies amidst of COVID-19 Pandemic}

The deadly COVID-19 forced all human activities to shut down abruptly, and the tourism sector, and education were mostly devastated (Kantei, 2020). The poor and vulnerable children who depend on school nutrition across the globe were severely affected since feeding at home became a problem (Kantei, 2020). Moreover, the measures adopted by the governments for implementing restricted lockdown to reduce infection rates affected less privileged families the most and tore them apart economically (Kantei, 2020). Most households could not meet three square meals per day. Despite, the government's efforts to give out 
transfer grants as well as palliatives, food packages and food parcels, numerous households could not be reached as a result of scarcity of resources (Kantei, 2020). Women, due to their sensitivity towards others, when compared to men, play a huge role in supporting individual and groups in distress in situations such as pandemics (Cavaliere, 2015).

In regards to that, religious organisations such as churches, temples and shrines waded in and heeded the call from the government to assist the destitute and needy as well as desperate families during the difficult times of pandemic. In Japan, Tokyo-based Shinnyoen donated 20 million yen to the non-governmental organisation (NGO's) which assists the families who were facing difficulty to get food to eat on daily basis. In other words, the families who cannot afford the three square meals in their homes (Cavaliere, 2020). Moreover, daycare was opened for ill children by Rissho Koseika in Tokyo with the name Segenanu, which implies Seeds Day-Care for the Sick.

The other services engaged on during the restricted lockdown as a humanitarian services by the religious bodies as they have been preaching, is donation of rain coats when the Personal Protective Equipment (PPE's) were in short supply at the Ministry of Health in Japan (https://www.sokanet.jp). The Osaka-based Shinnyneon (Buddhist denomination) donated 500 rain coats to the Ministry of Health to be used by the health personnel's as well as health related workers. Sokka-Gokkai Shinnyneon also donated 20 million yen to Tokyo and Osaka Prefectures who were hard hit by the COVID-19 pandemic infection (https://www.sokanet.jp). According to the Buddhist movement the aims of the donation is to assist the Prefectures to be able to defray huge cost incurred for the treatment of COVID-19 patients.

Furthermore, Qaman Churches in Osaka and Tokyo realised the agony, trauma, stress, anxiety and hopelessness bestowed on the people by the COVID-19 pandemic and decides to use expertise in their Church as counsellors and provided free counselling services to the general public (Allison, 2020). In addition, the church also provided accommodation to Tokyo and Osaka residents who lost their accommodation as a result of a state of emergency. The venue was named 'net café refugees' by Osaka Catholic Church (Cavaliere, 2020). Moreover, it was recorded that the COVID-19 pandemic affected the destitute and vulnerable the most and in that regard, shrines, temples, churches, schools were turned into places of residence to accommodate destitute and vulnerable in society (Cavaliere, 2020). In the study by Cavaliere (2020), churches, temples and shrines did not discriminate in regards to providing assistance to people who needed it. Both believers and non-believers were accommodated under their shelter and catered for (Cavaliere, 2019).

Christians have generally used traditional methods to meet through mass and church services. However, due to the pandemic, ways of worship have been transformed and it depends on the person on whether it is a good fit for them or not. The physical closing of churches has a negative impact on many people in terms of mental stability. For many believers, a church service is one of the important things people have in their life, and if they lose that it may make them sense they are being taken from.

\section{The Use of ICT and Challenges amidst of COVID-19 Pandemic}

It is maintained that there is nothing that comes easy in life. There is a price to pay for every decision we make in life. It is not different from migrating from the face-to-face worshiping to the use of online services. In fact, online services may have numerous advantages despite challenges faced when Churches, Shrines and Temples migrated to online services by the use of Zoom, Skype, Microsoft Teams, YouTube and Twitter. However, we need to remember that Churches are integral parts of their communities and are often on the front line when it comes to responding to disasters. When we look at historical epidemics, it is clear that churches are particularly well-placed to promote faith, trust and hope, as they build community and individual resilience. The COVID-19 pandemic has disrupted people's lives and many face mental distress disorders. So there are challenges that affect and have affected both religious leaders and the congregants. Most religious leaders who do not have acumen, 
technical know-how, or ideas about ICT struggle to cope with the current trend to be connected with their congregants. What even makes the migration from the face-to-face worshiping to the online so cumbersome and challenging is the abrupt manner in which a lockdown may be implemented as it does not give any room to anyone in order to equip him or herself for the online procedure before a migration to online worship (Amandi-Niché, 2020).A UNAIDS report "Rights in the Time of COVID-19 - lessons from HIV for an effective community-led response" offers a lot of guidance for communities to help meet vulnerable people's needs and rights. Communities must be part of decision-making, governance and monitoring and a peoplecentred approach must be maintained throughout the outbreak of a pandemic (UNAIDS, 2020).

While many churches, synagogues, mosques, and temples globally offered worship through livestream during the pandemic in Nigeria, and other nations there was inadequate advancement of the digital communication in the cities as well as in the localities the network creating grave concerns. Due to social-distancing guidelines, many churches needed to try to access alternatives to the usual face-to-face church services and turned to the digital church. However, sermons, worship and prayer transmissions were frequently interrupted by internet access issues. Thus, in some instances, networks unavailability denied congregants the 'soul food' or the word of God making other congregants lose hope in the hopeless situations created by the COVID-19 pandemic. The churches that do not have the resources to transit online bears the brunt, by losing revenue that usually accrue from the tithes, offerings and seed offerings (Amandi-Niché, 2020). Problems faced in Esikhaleni, the study area, were also found in highly developed nations such as Great Britain (Wyatt, 2020). The expense of acquiring gadgets such as laptop computers and mobile devices also posed challenges to the online transmission for the religious organisations. Most households could not afford the smart phones in order to be connected to the live programmes being broadcast by their denominations. As a result, we make some of the 'sheep' not to be fed with the word of God. In other words, some of the 'sheep' went astray while others benefited as a result of COVID19 pandemic.

Moreover, the least spoken about the exorbitant prices of data and airtime to connect to the programmes the better. What even makes it more challenging is the instances where individuals are at home without any income, and require help to purchase food and have basic needs met. Expensive data bundles needed for spiritual development become a huge problem (Amandi-Niché, 2020). South Africa remains the most unequal country in the world with a Ginicoefficient of 0.63 (Stats SA , 2020) and 14\% of South Africans still live in informal settlements, and do not even have decent housing and limited access to sanitation and water and $29 \%$ (The World Bank., 2014). It is not possible for many to begin to even contemplate buying a mobile phone or data required to be able to worship online,

The intermittent power interruption among most African countries was unbearable. Notably among them was Nigeria where the power supplies were frequently interrupted, making all activities such as songs and praises, worship and prayers, sermons and homilies sorely missed items. In some instances, the worshipers or congregants who were closer to the churches, shrines or temples usually rush to the places of worship to continue, because these places of worship-usually have generators that are used in cases where there are power interruptions. It must also be noted that the deadly pandemic has halted the services such as baptism evangelism and crusading. As a result, the probability for the decline in the number of congregants is not entirely ruled out, although fervent believers are likely to remain faithful to their religions.

\section{Methodology}

The underlying philosophy for the study was the phenomenological approach guided by $t$ qualitative research which is used to collect the data. Phenomenology is a method of qualitative research that focuses on the study of an individual's lived experiences within the 
world and was considered ideal for a study on COVID-19 effects. Phenomenology thus refers to the study of that which is seen and experienced by individuals and also groups (Ejizu \& Awajiusuk, 2013).

The qualitative approach is the best and most effective way to gather information and collect data when there is a need to know much about occurrences or events as they happen (Creswell, 2009). The qualitative approach is also significant and relevant because the research topic deals with the psycho-social effect of the Covid-19 pandemic and its impact on the religious activities of Esikhaleni dwellers during the lockdown, from $26^{\text {th }}$ March, to $30^{\text {th }}$ April, 2020 in South Africa. The qualitative research method used is explained by Corbin (2008) as a means of collecting data, interpreting, analysing and developing empirical ideas and understanding about the data collected. According to Creswell (2009) the qualitative approach method is the process of identifying human problems and analyse them and assigning meaning to them. The study area survey lasted for about five days. Permission was sought from the respondents who participated voluntarily. It was explained to the respondents that they were at liberty to withdrawal at any time if they felt uncomfortable in answering some or any of the questions posed. Moreover, all information collected would be deleted without any penalty. The findings will be kept in a safe place for up to five years after which they will be destroyed. The respondents remained anonymous throughout the study as all ethical requirements had to be met for the study to continue.

A purposive sample technique was used to gather the needed respondents up to the saturation level of 30 respondents. The services of a research assistant was employed because one of the researcher's was not able to speak competently in Zulu which is the local dialect of the Esikhaleni dwellers. The research assistant was briefed about the study aims, objectives and other expectations before the semi-structured interview were conducted via mobile phone usage. The use of mobile phones was necessary since the rules and regulations of the lockdown were still in place before data was collected. The data collected through the interviews was read over, proofread, coded and the emerging themes relevant to the study were identified. Thematic analysis was employed to evaluate the data and data was presented using narratives. Only relevant information was kept for the study.

\section{Discussions}

The discussion findings are based on the research objectives which are used as subheadings below

\section{Re-Branding Ways of Worship and Devotion amidst of COVID-19 Pandemic}

This research revealed that the majority of 28 respondents agreed that with the advent of COVID-19 and its knock-on effects in society, various plans and activities were cancelled. Most notably among them were crusades, baptisms, marriage ceremonies and circumcisions. A respondent explained:

We plan to have a grand marriage ceremony but it did not happened as a result of the COVID-19 pandemic.

Another respondent who happened to be a Church leader also added her voice by maintaining that:

We supposed to have crusades and win soul for God, but, it never materialised. Even our baptisms programme had been disrupted. However, the good Lord knows better.

The statements above indicate how THE COVID-19 pandemic prevented religious programmes and become an impediment to the church activities. This finding is in support of Douglas (1994) who posits that during the pandemic and its various crises, temples, shrines and churches normally cancelled or postponed programmes as well as other events in order to reduce the rate of infections. A respondent stated that: 
We are no more meeting to worship as we used to do, we only receive the bible verses and read them in our confinement.

The statement agrees with the findings of Cavaliere (2020) that sutras readings are posted online for the believers and monks to learn as well as memorise aspects of their faith during the lockdown periods.

\section{Embracing ICT amidst of COVID-19 Pandemic}

Most of the 27 respondent worshippers agreed to the use of ICT irrespective of the religious affiliations and denominations. They revealed that is the only way to cope with the anxiety and hopelessness which the deadly COVID-19 has bequeathed them. This is what one of the respondents had to say:

Once we were asked not to meet, we decided to share the 'soul food' through online mediums such as Zoom and Skype.

The finding aligns with the McLaughlin (2020) study which confirms that various religious bodies avoid personal meetings for teaching the word of God and have resorted to the use of online services. Another respondent also maintained that:

The digital transmission of the messages from the church is very powerful and is embraced by almost all the congregants. We are very grateful for this initiative.

The statement is in support of findings of Wodobo (2020) and Zikini (2020) that various mediums are used other than conventional methods of congregants meeting for praise and worship. What is intriguing about the statement is that, despite the fact that theCOVID-19 pandemic bestows disaster on mankind there are still some positive aspects as members turn to enjoy the online transmission for their religious activities. This confirms that in every situation there can be positive as well as negative aspects. It depends on what an individual takes out of what is happening around them.

\section{Benevolent Roles of Religious Bodies amidst of COVID-19 Pandemic}

Giving of arms as one of the pillars of Islam religion was also practice by almost all the religious institutions. Most respondents 25 agreed that their denominations contributed and assisted the needy as well as the destitute in society. This is one of the respondents views:

You know that alms giving is one of our pillar in Islam, we assisted a lot of destitute and paid some medical bills.

The statement above indicates that the person is a Moslem. He was expressing how assisting the needy in society is the bedrock of the Islamic religion. The statement is in support of the study by Cavaliere (2020) who reveals that the Buddhism donated sums of money to the various Prefectures to enable them to defray the cost of COVID-19 medical bills. Another respondent also maintains that:

Our Shrine packages food parcel as well as clothes to the vulnerable in society to give them hope.

Another respondent also explained that:

We have experts' counsellors in our church, we requested them to provide services to the individuals, families as well as households who may need it without paying a cent.

The above statements are in agreement with the findings of Kantei (2020) who reveals that religious bodies in Japan provided services to the needy and destitute in society for free. The counselling services provisioning conforms to the findings of Allision (2020) in Japan by the various religious bodies. 


\section{The Use of ICT and Challenges amidst of COVID-19 Pandemic}

It is very interesting to find out when the whopping majority of 29 agreed about the challenges with regard to the migration from face-to-face worshiping to online services. Both leaders and congregants expressed their displeasure to some extent. This is what one of the respondents had to say:

It is very boring to worship in the house alone. You cannot feel the presence of God.

Another respondent also added her voice in that:

Getting network connections to screen live programmes is a daunting task.

The statements indicate that some of the congregants do not like the online transmission of services of sermons at all and feel somewhat alienated. It could be that they are used to the conventional meetings or they are laggards in society who will later adopt the use of IT. However, the statements support Amandi-Niché (2020) who claimed that in Nigeria some of the members of religious institutions expressed their great displeasure about online transmissions of religious activities. Another respondent also maintained that:

\section{In fact, this is frustrating, you know what, when you are in the spirit to receive} more 'rhema' words that is when the power interruption occurs.

Another respondent also revealed that:

It could be the work of the devil. Anytime, there is the word of God the network connections start to possess problem. However, we are an overcomer.

The statements reveal how infrastructure development is a problem in the Esikhaleni Township which possesses a problem of frequent network interruptions. It further explains how the regular power interruption in South Africa which is termed load-shedding impacts on communities. However, the statement supports the finding of Amandi-Niché (2020), that across the African continent and especially in Nigeria, power supply as well as networks connection are major problems that hinder online forms of message delivery or communication. The problem is then somewhat continental in nature, if not global.

\section{Conclusions and Recommendations}

This paper reveals that Durkhein's ideas of functional religion in Sociology maintain that the human race should be together, share solace and love with especially the destitute in society (Durkhein, 2005). However, the COVID-19 pandemic protocols defy such an idea and ask people to rather observe social distancing as well as physical distancing in order to curb the infection rate (WHO, 2020). As a result, organisations, institutions and social gatherings were halted, which posed challenges to various institutions especially the religious bodies to meet, and then praise as well as worship. People in Churches then resorted to online approaches such as Zoom, Skype, YouTube, WhatsApp to deliver the word of God. Some religious organisations use the period to postpone the major events on their calendar such as baptisms, crusading, evangelism, and even Hajj pilgrimages among others. Further, the catastrophe bestowed by the COVID-19 pandemic on the destitute and needy in society forced the religious bodies to extend their arms in diverse ways to assist them. However, the study reveals that there were challenges for migrating from conventional worshiping to online services.

Among the problems identified are leaders and congregants not having the technical knowhow or acumen to handle online programmes, network connectivity, intermittent power interruption, and the high cost of data as well as mobile devices prices. We need to commend many Churches and other faiths and recognize their efforts to support adherents in worshipping by providing needed online services. As our faith is sorely tested, we need to keep praying for deliverance. 
Religious leaders must urgently become be ICT compliant in order to get used to modern trends such as the use of modern technological devices and applications for Churches. Religious institutions need to incorporate information and communication technology in plans for future growth. Poverty certainly alienates and also undermines an individuals' capacity to respond to the current pandemic when it comes to faith based issues and religious observances when they can't even afford basic items, let alone the needed technology. Religious orders need to urgently embrace technological solutions which is sadly not always possible due to limited resources. Getting the masses out of poverty through job creation would also go a long way to help when future pandemics arise, and they surely will.

Therefore, the study recommends that religious leaders should as a matter of urgency learn the use of ICT, because the COVID-19 pandemic might be here for some time. Faiths must seek alternative spaces and digital ways in which to reformulate metaphysical beliefs and collective religious-cultural practices. Moreover, religious leaders must educate and inform their congregants to observe the COVID-19 protocols so as to avoid an imminent third wave instead of accusing the government of not being supportive to their plight.

\section{References}

Arons, M.M., Hatfield, K.M., Reddy, S.C., Kimball, A., James, A., Jacobs, J.R., Taylor, J., Spicer, K., Bardossy, A.C., Oakley, L.P. \& Tanwar, S. (2020). Presymptomatic SARS-CoV-2 infections and transmission in a skilled nursing facility, New England Journal of Medicine, 382(22), 2081-2090.

Awoshiri, W. P. (2020). "Corona Virus: Biblical Understanding on Disease and Sickness", Jalingo Journal of Christian Religious Studies, 7 November, 2020, 183-195.

Baker, J. O., Martí, G., Braunstein, R., Whitehead, A. L. \& Yukich, G. (2020). Religion in the Age of Social Distancing: How COVID-19 Presents New Directions for Research, Sociology of Religion, 81 (4), 357-370. [Available online at https://doi.org/10.1093/socrel/sraa039]

Brouwer, J. \& Mulder, A. (Eds.) (2007). Information Is Alive. [Available online at https://v2.nl/publishing/information-is-alive]

Cavaliere, K., Levine, C., Wander, P., Sejpal, D.V. \& Trindade, A.J. (2020). Management of upper GI bleeding in patients with COVID-19 pneumonia, Gastrointestinal endoscopy, 92(2), 454-455

Cavaliere, P. (2015). Promising Practices: Women Volunteers in Japanese Religious Civil Society, Leiden: Brill.

Church-Hill, A.N. (2021).ICT: A Coping Strategy by Nigerian Churches amidst Covid-19 Pandemic. Research Journal of Humanities and Cultural Studies, 7(1).

Dileep, N.P., Vineesh, T.V., Sarma, P.V., Chalil, M.V., Prasad, C.S. \& Shaijumon, M.M. (2020). Electrochemically exfoliated $\beta-\mathrm{Co}(\mathrm{OH}) 2$ nanostructures for enhanced oxygen evolution electrocatalysis. ACS Applied Energy Materials, 3(2), 1461-1467.

Ebrahim, S.H. \& Memish, Z.A.(2020). COVID-19: preparing for superspreader potential among Umrah pilgrims to Saudi Arabia, The Lancet 395(10227), e48.

Ejizu, C. I. \& Awajiusuk, J.F. (2013). The Phenomenological Perspective, Ejizu C.I (ed)., Fundamentals of Research Methodology in the Humanities. Port Harcourt: University of Port Harcourt Press, 2013

Folegatti, P.M., Ewer, K.J., Aley, P.K., Angus, B., Becker, S., Belij-Rammerstorfer, S., Bellamy, D., Bibi, S., Bittaye, M., Clutterbuck, E.A. \& Dold, C.(2020). Safety and immunogenicity of the ChAdOx1 CoV-19 vaccine against SARS-CoV-2: a preliminary report of a phase 1/2, single-blind, randomised controlled trial, The Lancet, 396(10249), 467-478. 
Frey, N.L. (2004.) Pilgrimage and its aftermath. In Badone E and Roseman SR (eds) Intersecting Journeys: The Anthropology of Pilgrimage and Tourism, Chicago: University of Illinois Press, 89-109.

Gautret, P. \& Steffen, R. (2016). Communicable diseases as health risks at mass gatherings other than Hajj: what is the evidence? International Journal of Infectious Diseases, 47, 46-52.

Kang, L., Ma, S., Chen, M., Yang, J., Wang, Y., Li, R., Yao, L., Bai, H., Cai, Z., Yang, B.X. \& $\mathrm{Hu}, \mathrm{S}$. (2020). Impact on mental health and perceptions of psychological care among medical and nursing staff in Wuhan during the 2019 novel coronavirus disease outbreak: A crosssectional study, Brain, behavior, and immunity, 87,11-17.

Kantei, (2020). Cabinet Office of Japan. Covid-19] Declaration of a State of Emergency in response to the Novel Coronavirus Disease (April 7). [Available online at https://japan.kantei.go].jp/ongoingtopics/_00018.html (accessed 29 May 2020).

Mbogo, R.W., (2020). Leadership Roles in Managing Education in Crises: The Case of Kenya during Covid-19 Pandemic, European Journal of Education Studies, 7(9).

McGuire, M. B. (2008). Lived Religion: Faith and Practice in Everyday Life. New York: Oxford University Press.

Ebrahim, S. H., \& Memish, Z. A. (2020). COVID-19: preparing for superspreader potential among Umrah pilgrims to Saudi Arabia. Lancet, 395(10227), e48. [Available online at https://doi.org/10.1016/S0140-6736(20)30466-9]

Nicolaides, A. (2016) Marian Tourism: Eastern Orthodox and Roman Catholic pilgrimage, African Journal of Hospitality, Tourism and Leisure, 5(4).

Nzabahimana, I., Mpunga, T., Karenzi, A. \& Umubyeyi, A. (2014). Food borne outbreak of salmonellosis at a church gathering, Rwanda, 2012, International Journal of Infectious Diseases, 21, 105-106.

Parker, S.K., Williams, H.M. \& Turner, N. (2006). Modeling the antecedents of proactive behavior at work, Journal of applied psychology, 91(3), 636.

Robinson, K. (2020). How Are Major Religions Responding to the Coronavirus? March 19, 2020- Council on Foreign Relations 100 [Available online at https://www.cfr.org/in-brief/howare-major-religions-responding-coronavirus]

Shafi, A.S. \& Weerakkody, V. (2009). August. Understanding citizens' behavioural intention in the adoption of e-government services in the state of Qatar. In ECIS (Vol. 1, pp. 1618-1629).

Stats SA (2020). [Available online at http://www.statssa.gov.za/]

The World Bank. (2014). GINI index (World Bank estimate) [Available online at https://data.worldbank.org/indicator/SI.POV.GINI?locations=ZA\&most_recent_value_desc=tr ue]

UNAIDS (2020). Rights in the time of COVID -19Lessons from HIV for an effective, community-led response. [Available online at

https://www.unaids.org/sites/default/files/media_asset/human-rights-and-covid-19_en.pdf]

Van Bavel, J.J., Baicker, K., Boggio, P.S., Capraro, V., Cichocka, A., Cikara, M., Crockett, M.J., Crum, A.J., Douglas, K.M., Druckman, J.N. \& Drury, J. (2020). Using social and behavioural science to support COVID-19 pandemic response, Nature human behaviour, 4(5), 460-471.

Wobodo, J.J. (2020). The church utility of ICTs in Nigeria amid covid-19 global pandemic, Sapientia global Journal of Arts, Humanities and Development Studies, 3(3). 
World Health Organization, (2020). The WHO recommended classification of pesticides by hazard and guidelines to classification 2019. World Health Organization. [Available online at https://www.who.int/publications/i/item/9789240005662]

Worldometer, C.C., Worldometer. (2020) 1-22. Doi, 10(2020.01), pp.23-20018549.

Wotogbe-Weneka, W. O. (2012). "The place of Religious Values in National Development" in U. M. Ivowi, U. M. Orubite, W. W. Wodi (ed), VALUES EDUCATION AND NATIONAL DEVELOPMENT, Paper Worth Books: Port Harcourt,,

Wyatt, T. (3 March 2020). Coronavirus: Impact on UK Churches, Religion Media Centre. [Available online at https://religionmediacentre.org.uk/factsheets/impact-of-coronavirus-onchurches-march-2020/]

Zamoum, K. \& Gorpe, T.S. (2018). Crisis Management: A Historical and Conceptual Approach for a Better Understanding of Today's Crises. [Available online at http://dx.doi.org/10.5772/intechopen.76198] 